\title{
Medidas de eficiencia técnica para pequeños productores de leche del Sur de Chile: Un análisis con fronteras estocásticas y datos de panel desbalanceado
}

\author{
Technical efficiency measures for small dairy farms in Southern Chile: A stochastic frontier \\ analysis with unbalanced panel data
}

\author{
V H Moreira ${ }^{1}$ *, B E Bravo-Ureta ${ }^{2}$, B L Carrillo ${ }^{3}$, J A Vásquez ${ }^{4}$ \\ ${ }^{1}$ Ph.D. Student, Department of Agricultural and Resource Economics, University of Connecticut, Storrs, CT, USA, and \\ Assistant Professor, Department of Agricultural Economics, Universidad Austral de Chile, Valdivia, Chile. \\ ${ }^{2}$ Executive Director Office of International Affairs and Professor of Agricultural and Resource Economics, University of \\ Connecticut, Storrs, CT, USA. \\ ${ }^{3}$ Assistant Professor, Department of Food Science and Technology, Universidad Austral de Chile, Valdivia, Chile \\ ${ }^{4}$ Manager, Paillaco Farm Management Center, Chile.
}

\begin{abstract}
SUMMARY
This paper uses a stochastic production frontier model to measure technical efficiency and technological change for a sample of small dairy farms in Southern Chile. The data is a highly unbalanced panel including 48 farmers with a total of 92 observations covering the period from 1996/97 to 2001/02. All farmers in the sample are members of the Paillaco Farm Management Center (FMC). In the preferred model, the inefficiency term has a half-normal distribution, there is no agro-climatic effect and the presence of technical inefficiency is highly significant and time variant. Average technical efficiency ranges from 77\% (1996/97) to 69\% $(2000 / 01)$ and technological change is significant and increases at an average annual rate of $8.6 \%$ for the period (1996/2002). On average, the farmers in the sample from Paillaco (Southern Chile) are operating at a sub optimal size given that the computed returns to size parameter is equal to 1.12 .
\end{abstract}

Palabras clave: fronteras estocásticas, eficiencia técnica, datos de panel, predios lecheros.

Key words: Stochastic frontiers, technical efficiency, panel data, dairy farms.

\section{INTRODUCTION}

Over the past several years, Chile has been adopting a wide range of economic reforms in an attempt to consolidate a modern free market system that is open to international trade. In this context, the commercial agreements signed by Chile have imposed a new scenario to all economic agents within the country. Increasing competition from imported products presents special challenges to traditional agricultural areas such as Southern Chile where dairy and wheat production are significant components of the farm economy. A critical response to the challenges coming from foreign imports is for agricultural producers to increase their productivity in order to remain competitive and ultimately to remain in business (Vargas 2000).

Data for the Chilean dairy sector show that from 1986 to 2001 , national milk production grew at an $8.1 \%$ aver-

Aceptado: 09.08.2005.

* Fax 1-860-4861932. Emails: Victor.Moreira@uconn.edu or vmoreira@uach.cl. Address: W.B Young Building 1376 Storrs Road, Storrs, Connecticut 06269-4021, USA. age annual rate while from 1990 to 2000 prices received by farmers experienced a steady decline. In 2000, the Chilean average milk price was 30\% lower than in 1990 (Guichapani, 2004). Such persistent deterioration in dairy farm prices has brought a great deal of uncertainty to the sector posing major challenges to the prosperity of small and medium sized farms in particular. These statistics also point to the importance of improving the performance of dairy farms (Instituto Interamericano de Cooperación para la Agricultura 2002).

Recognizing the challenges and opportunities associated with opening up the economy, the Chilean government has made important efforts to facilitate the adoption of new technologies and to improve managerial performance in order to increase farm productivity and competitiveness. One such effort has been the introduction of Farm Management Centers (FMCs) who have as a major goal the training of producers so that they become better managers and thus increase their productivity. An integral part of most FMCs is to gather production and socioeconomic information directly from participating farmers, which provides a valuable resource for analytical work and policy formulation (Sandoval and Gómez 1999). 
In Southern Chile, there are several FMCs focusing on assisting small dairy farms, one of which is located in the town of Paillaco, in Region X, the major milk producing area of the country (Anrique, 1999). The Paillaco FMC was initiated in December of 1995 as a collaborative effort between the Agricultural Development Institute (INDAP), which is a branch of the Chilean Ministry of Agriculture, and Universidad Austral de Chile in Valdivia, Chile. The Paillaco FMC includes eight Milk Collection Centers (MCCs) with 545 farmers distributed over three municipalities: Paillaco, Los Lagos and Futrono (Sandoval and Gómez 1999).

Given that FMCs were designed with the specific goal of improving farm productivity, this paper will explore this hypothesis. Specifically, we will test the null hypothesis that technical efficiency has been time invariant over a period of years starting with the formation of the Paillaco FMC, using information from the eight MCCs. If this hypothesis is rejected and technical efficiency is found to increase over time then this finding would be consistent with one of the primary goals of the FMC concept. In addition, we will test the hypothesis that technological change has been constant over time. If this hypothesis is rejected and technological change is found to be positive then this would also be consistent with the goal of the FMCs.

This study makes a significant contribution to the agricultural productivity literature focusing on Chile because, despite the many studies published on dairy farm technical efficiency worldwide, no such paper has been found for this country. This is evident from the extensive metaanalysis of the dairy farm efficiency literature recently completed by Rivas (2003).

The article is structured as follows: the second section discusses the stochastic frontier model for unbalanced panel data. The third section presents the data and empirical model followed by a discussion of the results. The last section contains some concluding remarks.

Stochastic Frontier Model. Several papers using panel data for dairy farms focusing on technical efficiency measurement have been published. Some applications of stochastic production frontiers to dairy using panel data include the papers by Ahmad and Bravo-Ureta (1995 and 1996), Bailey et al (1989), Battese and Coelli (1988), Cuesta (2000), Heshmati and Kumbhakar (1994), Kumbhakar and Hjalmarsson (1993), Kumbhakar and Heshmati (1995), and Reinhard et al (1999). The stochastic frontier model used here was introduced by Battese and Coelli (1992 and 1995) and has been applied by several researchers including Ahmad and Bravo-Ureta (1995 and 1996), Battese and Broca (1997), Alvarez and Gonzales (1999), Rezitis et al (2002), and Cullinae and Song (2003). The model assumes that data are available for a sample on $N$ firms over $T$ time periods, although the panel does not have to be balanced.
The model used in this study follows the Battese and Coelli framework (1992 and 1995), which has gained considerable popularity in recent years. According to Battese and Coelli (1992), the stochastic frontier production function can be written as:

$$
Y_{i t}=\exp \left(x_{i t} \beta+V_{i t}-U_{i t}\right)
$$

where $Y_{i t}$ denotes the output for the $i^{\text {th }}$ farm in the $t^{\text {th }}$ time period; $x_{i t}$ denotes a $(1 \infty K)$ vector of inputs and other explanatory variables for the $i^{\text {th }}$ farm in the $t^{\text {th }}$ time period; $\beta$ is a $(K \infty l)$ vector of unknown parameters to be estimated; $V_{i t}$ is a random error assumed to follow a normal distribution with mean zero and constant variance $\left(v_{i} \sim \operatorname{iid} N\left(0, \quad \begin{array}{l}2 \\ v\end{array}\right)\right.$ ); and $U_{i t}$ is a non-negative unobservable random error associated with the technical inefficiency of the $i^{\text {th }}$ farm.

Following Battese and Coelli (1992), $U_{i t}$ can be defined as:

$$
U_{i t}=\{\exp [-\eta(t-T)]\} U_{i}
$$

where $\eta$ is an unknown scalar to be estimated. Technical efficiency increases, remains constant or decreases over time, when the value of $\eta>0, \eta=0$ or $\eta<0$, respectively.

The $U_{i t}$ term can have different specifications. Two frequently used specifications are the non-negative truncation of a normal distribution with a mean $\mu$ and constant variance $\left(U_{i} \sim i i d / N(\mu, \quad 2) /\right)$ and the half normal distribution $\left(U_{i} \sim\right.$ iid $\left./ N\left(0, \quad \begin{array}{l}2 \\ )\end{array}\right)\right)$. Coelli et al (1998) suggest that the choice of a more general distribution, such as the truncatednormal distribution, is usually preferable. This is ultimately an empirical issue and, therefore, in this paper the truncated-normal distribution is tested against the half-normal.

Kumbhakar et al (1991), and Reifschneider and Stevenson (1991) proposed stochastic frontier models in which the inefficiency effects $\left(U_{i}\right)$ are expressed as an explicit function of a vector of firm-specific variables and a random error. Battese and Coelli (1995) proposed a model that is equivalent to the Kumbhakar et al (1991) specification, but relaxes assumptions concerning profit maximization and accommodates panel data.

The Battese and Coelli (1995) specification may be expressed in the same way that equation 1, but now the $U_{i t}$ are non-negative random variables which are assumed to account for technical inefficiency in production and to be independently distributed as truncations at zero of the $/ N\left(z_{i t}\right.$ $\left.\delta, \begin{array}{l}2 \\ U\end{array}\right)$ /distribution. Therefore, the inefficiency effects, $U_{i t}$, in the stochastic frontier model (equation 1) can be expressed as:

$$
U_{i t}=z_{i t} \delta+W_{i t}
$$

where $W_{i t}$ is a random variable defined by the truncation of the normal distribution with zero mean and variance 
$\sigma^{2}, z_{i t}$ is a $(p \infty 1)$ vector of variables which may influence the efficiency of a firm, and $\delta$ is a $(l \infty p)$ vector of parameters to be estimated.

The technical efficiency for the $i^{\text {th }}$ farm is given by:

$$
T E=\exp \left(-U_{i}\right)
$$

where $U$ is specified in equations (1) and (2). The technical efficiency for each firm is calculated using the conditional expectation of $e^{(-U)}$, given the composed error term of the stochastic frontier model (Jondrow et al 1982, Battese and Coelli 1988).

Considering the above specifications, it is of interest to test the null hypothesis that the technical inefficiency effects are not present in the model, which is equivalent to the null hypothesis that $\gamma=0$. The parameter $\gamma$, which must lie between 0 and 1 , is equal to the ratio of the variance of the one sided error term to the total variance or $\gamma={ }_{U}^{2} /\left(\begin{array}{l}2 \\ v\end{array}{ }_{U}^{2}\right)$ (Battese and Corra 1977). In addition, the null hypotheses that the technical inefficiency effects are time invariant $\left(H_{0}: \eta=0\right)$ and that they have a half-normal distribution $\left(H_{0}: \mu=0\right)$, are tested. Finally, the null hypothesis that the agro-climatic zone where a farm is located does not affect efficiency is also evaluated.

Data and Empirical Model. The data for this study comes from 48 small dairy farms located in Southern Chile for the periods 1996/97, 1998/99, 1999/00, 2000/01 and $2001 / 02$. Unfortunately, there is no information for the period 1997/98 because resource constraints and other more pressing needs did not permit the Paillaco FMC in that year to allocate funds for farm data collection. All the data is from members of the Paillaco FMC, located in the town of Paillaco, Region $\mathrm{X}$ in Chile who deliver their milk to one of eight different MCCs: Paillaco, Reumén, Pucara, Ustaritz, La Misión, Pichirropulli, Pumol and Santa Rosa. The number of observations available per farm varies considerably, ranging from 1 to 5. Pooling all data available yields a total of 92 observations; hence, the panel is highly unbalanced (table 1).

Table 2 shows the descriptive statistics for the dairy farms under study. Average milk production per farm per year is 55.010 liters and ranges from 8.310 to 182.537 liters. The standard deviations indicate that there is considerable variation among farms. The average herd size for the period was 25 cows, ranging from 5 to 83 cows. The average per farm use of other inputs, i.e. Feed and Labor, for the period of analysis was $\mathrm{Ch} \$^{1} 1.810,000$ and $\mathrm{Ch} \$ 1.613,000$ in real terms ${ }^{2}$, respectively.

A single equation Cobb-Douglas production frontier model is used in this study where the dependent variable is the natural logarithm of annual per farm milk output $(Y)$ measured in liters. Ideally, a multi-output analysis would be formulated (e.g., milk, beef, crops, etc.); however, the data available for this study did not make this possible. Nevertheless, it is important to stress that all inputs included in the production model are those assigned to the milk production activity.

Three alternative specifications of the Battese and Coelli (1995) model are formulated and estimated. In the reference model, Model 1, the inefficiency term has a halfnormal distribution, is time variant and does not incorporate explanatory variables in the error term. The remaining two models incorporate different assumptions and specifications concerning the production frontier part of the model (Model 2) and the technical inefficiency term (Model 3).

The first production frontier model (Model 1), can be written as:

$$
Y_{i t}=\beta_{0}+\beta_{C} \text { Cows }_{i t}+\beta_{F} \text { Feed }_{i t}+\beta_{L} \text { Labor }_{i t}+\sum \beta_{t} D T_{t}+V_{i t}-U_{i t}
$$

where the subscripts $i$ and $t$ refer to the $i^{\text {th }}$ farm in the $t^{\text {th }}$ time period. The explanatory variables are defined as follows:

Cows $=$ is the logarithm of the average number of dairy cows in production,

Feed $=\quad$ is the logarithm of the total value of purchased feed, including concentrate feed, hay and minerals, plus all costs associated with the production of hay and silage, and expenditures on the establishment and maintenance of pastures, all measured in Chilean pesos for the period 2002/03,

Labor $=$ is the logarithm of total value of labor, including family and hired workers, measured in Chilean pesos for 2002/03. The Chilean minimum wage is used to value family labor,
$D T_{t}=\quad$ is a set of dummy variables where $\mathrm{t}=1,2,3,4$ and $5(1=1996 / 97 ; 2=1998 / 99 ; 3=1999 / 00 ; 4=$ 2000/01; 5=2001/02),

$V_{i t}, U_{i t}=$ are random variables as already defined; and $\beta=\quad$ are unknown parameters to be estimated.

The $D T_{\mathrm{t}}$ dummy variables are introduced to account for the effect of time or technological change on output.

Considering that the MCCs are located in three different agro-climatic zones, a set of zone dummy variables $\left(Z_{z}\right)$ is introduced in Model 2 to account for this effect (see Equation 6 below). The zones were defined

Read as Chilean Pesos.

2 The reference year for all data in Chilean Pesos is July 2002-June 2003 or $2002 / 03$. For that year, on average, one US dollar was equal to Ch\$ 650 . 
in terms of weather and soil characteristics with the help of local professionals affiliated with the MCCs. The zones are defined as follows: Zone $1\left(Z_{l}\right)$ covers Paillaco, Reumén and Pichirropulli; Zone $2\left(Z_{2}\right)$ includes Pucara, Ustaritz and La Misión; and Zone $3\left(Z_{3}\right)$ consists of Pumol and Santa Rosa. The potential importance of agro- climatic variability on efficiency analysis has been articulated recently by Demir and Mahmud (2002). In sum, the production frontier for Model 2 (equation 6) is the same as Model 1 (equation 5), but the former incorporates the agro-climatic dummies. Model 2 can be expressed as:

$$
Y_{i t}=\beta_{0}+\beta_{C} \text { Cows }_{i t}+\beta_{F} \text { Feed }_{i t}+\beta_{L} \text { Labor }_{i t}+\sum \beta_{t} D T_{t}+\sum \beta_{z} Z_{z}+V_{i t}-U_{i t}
$$

Model 3 is the same as Model 1, but includes the variables $T$ (time) and $T T$ (time squared) in the technical inefficiency term and it can be expressed as:

$$
U_{i t}=\delta_{0}+\delta_{T} T_{t}+\delta_{T T} T T_{t}+W_{i t}
$$

where:

$W_{i t}=$ is a random variable defined by the truncation of the normal distribution with zero mean and variance $\sigma^{2}$, and

$\delta=$ are unknown parameters to be estimated.

To calculate the impact of technological change it is useful to rewrite the Cobb-Douglas production function as (Ahmad, 1994):

$$
Y_{i t}=\hat{A}_{t}+\hat{T E}_{i t}+\sum \hat{b} \ln X_{i t}
$$

where the first term on the right hand side of equation (8), $\hat{A}_{t}$, represents the logarithm of technological change, the second term, $\hat{T E}_{i t}$, is the logarithm of the technical efficiency component, and the last terrn, $\sum \hat{b} \ln X_{i t}$, is the change in output associated with the change in inputs or the size effect.

Calculating the total derivative of equation (8) with respect to time, yields a term for the rate of technological

Table 1. Number of farmers by period and $\mathrm{MCC}^{1}$ Número de productores por período y $\mathrm{CAL}^{2}$

\begin{tabular}{lccccc}
\hline Period & $1996-97$ & $1998-99$ & 1999-00 & 2000-01 & 2001-02 \\
\hline MCC & & & & & \\
Paillaco & 0 & 4 & 0 & 0 & 2 \\
Reumén & 0 & 3 & 0 & 0 & 0 \\
Pucara & 0 & 4 & 0 & 0 & 2 \\
Ustaritz & 0 & 4 & 0 & 0 & 1 \\
La Misión & 8 & 6 & 7 & 3 & 0 \\
Pichirropulli & 4 & 3 & 5 & 3 & 2 \\
Pumol & 3 & 4 & 5 & 1 & 1 \\
Santa Rosa & 5 & 5 & 1 & 3 & 3 \\
\hline Total & 20 & 33 & 18 & 10 & 11 \\
\hline
\end{tabular}

1 Milk collection Center.

2 Centro de Acopio Lechero. change which is equal to $\frac{\partial \hat{A}_{\mathrm{t}}}{\partial D T}$. When the effect of time is incorporated with dummy variables, as is the case here, the latter expression can be approximated by:

$$
\frac{\partial \hat{A}_{t}}{\partial D T}=\left(\hat{A}_{t}-\hat{A}_{t-1}\right)
$$

where $\hat{A}_{t}$ is equal to $\beta_{t} D T_{t}($ Ahmad 1994).

Table 2. Descriptive statistics for Chilean small dairy farms

\begin{tabular}{|c|c|c|c|c|}
\hline Variable & Mean & $\begin{array}{l}\text { Stand. } \\
\text { Dev. }\end{array}$ & $\begin{array}{l}\text { Min. } \\
\text { Value }\end{array}$ & $\begin{array}{l}\text { Max. } \\
\text { Value }\end{array}$ \\
\hline \multicolumn{5}{|l|}{ A. All farms } \\
\hline Milk $\left(1\right.$ year $\left.^{-1}\right)$ & 55,010 & 47,929 & 8,310 & 182,537 \\
\hline Cows (Number) & 25 & 15 & 5 & 83 \\
\hline Feed value $\left(\mathrm{Ch} \$^{3}\right)$ & 1,810 & 2,713 & 0 & 14,652 \\
\hline Labor $\left(\mathrm{Ch} \$^{3}\right)$ & 1,613 & 1,182 & 461 & 7,650 \\
\hline Land $(\mathrm{Ha})$ & 42 & 26 & 2.25 & 144 \\
\hline \\
\hline & \multicolumn{4}{|c|}{ Agro-climatic zones ${ }^{4}$} \\
\hline Zone $1\left(\mathrm{Z}_{1}\right)$ & 0.283 & & & \\
\hline Zone $2\left(Z_{2}\right)$ & 0.380 & & & \\
\hline Zone $3\left(\mathrm{Z}_{3}\right)$ & 0.337 & & & \\
\hline \multicolumn{5}{|c|}{$\begin{array}{l}\text { B. By agro-climatic zone } \\
\text { Zone } 1\end{array}$} \\
\hline Milk (1 year $\left.{ }^{-1}\right)$ & 73,795 & 60,823 & 8,310 & 182,537 \\
\hline Cows (Number) & 27 & 16 & 6 & 57 \\
\hline Land $(\mathrm{Ha})$ & 44 & 36 & 9 & 144 \\
\hline \multicolumn{5}{|l|}{ Zone 2} \\
\hline Milk (1 year-1) & 33,830 & 21,801 & 9,433 & 108,284 \\
\hline Cows (Number) & 19 & 10 & 5 & 51 \\
\hline Land (Ha) & 42 & 21 & 10 & 120 \\
\hline \multicolumn{5}{|l|}{ Zone 3} \\
\hline Milk (1 year-1) & 63,167 & 49,482 & 10,287 & 177,484 \\
\hline Cows (Number) & 30 & 17 & 7 & 83 \\
\hline Land (Ha) & 41 & 23 & 2.25 & 65 \\
\hline
\end{tabular}
from the Paillaco FMC ${ }^{1}$

Estadísticas descriptivas para predios de pequeños productores lecheros del $\mathrm{CEGE}^{2}$-Paillaco

\footnotetext{
1 Farm Management Center.

2 Centro de Gestión.

3 1,000 Chilean pesos

${ }^{4}$ Distribution of the number of farms per zone, e.g. 0.283 indicates that $28.3 \%$ of the farms are in Zone 1
} 
EMPIRICAL RESULTS. Table 3 shows maximum-likelihood parameter estimates for the three models (Models 1, 2 and 3), all obtained using the FRONTIER 4.1 software (Coelli 1996). The three models exhibit highly significant parameter estimates in the production function part of the model. All parameters are significant at the $1 \%$ level, except for those corresponding to Feed for Model 1 and 2, Labor for Model 2 and 3, $D T_{2}$ for Model 1 and 2 and $D T_{3}$ for Model 2 that are significant at the 5\% level. The variables for the agro-climatic effects are not significant and will be analyzed below.

Table 3. Maximum likelihood parameter estimates for three stochastic production frontiers.

Parámetros de máxima verosimilitud para tres fronteras de producción estocásticas.

\begin{tabular}{|c|c|c|c|c|}
\hline Variables & Parameter & Model 1 & Model 2 & Model 3 \\
\hline Constant & $\beta_{0}$ & $\begin{array}{l}6.148^{* * * 1} \\
0.536^{2}\end{array}$ & $\begin{array}{l}6.393^{* * *} \\
0.564\end{array}$ & $\begin{array}{l}6.489^{* * *} \\
0.594\end{array}$ \\
\hline Cows & $\beta_{\mathrm{C}}$ & $\begin{array}{l}0.832^{* * *} \\
0.083\end{array}$ & $\begin{array}{l}0.856^{\text {*** }} \\
0.084\end{array}$ & $\begin{array}{l}0.915^{* * *} \\
0.072\end{array}$ \\
\hline Feed & $\beta_{\mathrm{F}}$ & $\begin{array}{l}0.034^{* * *} \\
0.014\end{array}$ & $\begin{array}{l}0.035^{* *} \\
0.014\end{array}$ & $\begin{array}{l}0.038^{* * *} \\
0.011\end{array}$ \\
\hline Labor & $\beta_{\mathrm{L}}$ & $\begin{array}{l}0.250^{* * *} \\
\underline{0.093}\end{array}$ & $\begin{array}{l}0.216^{* *} \\
0.094\end{array}$ & $\begin{array}{l}0.184^{* *} \\
0.101\end{array}$ \\
\hline $\mathrm{DT}_{2}^{3}(1998 / 99)$ & $\beta_{\mathrm{DT} 2}$ & $\left(\underline{0.158^{* * *}}\right.$ & $0.148^{* *}$ & $\left.0.228^{* *}\right)$ \\
\hline $\mathrm{DT}_{3}(1999 / 00)$ & $\beta_{\mathrm{DT} 3}$ & $\begin{array}{l}\frac{0.067}{0.293^{* * *}} \\
0.091\end{array}$ & $\begin{array}{l}\frac{0.072}{0.267^{* *}} \\
0.101\end{array}$ & $\begin{array}{l}\frac{0.068}{0.335^{* *}} \\
0.081\end{array}$ \\
\hline $\mathrm{DT}_{4}(2000 / 01)$ & $\beta_{\mathrm{DT} 4}$ & $\begin{array}{l}0.538^{* * *} \\
0.127\end{array}$ & $\begin{array}{l}0.496^{* * *} \\
0.140\end{array}$ & $\begin{array}{l}0.0525^{* * *} \\
0.093\end{array}$ \\
\hline $\mathrm{DT}_{5}(2001 / 02)$ & $\beta_{\mathrm{DT5}}$ & $\begin{array}{l}0.517^{\text {*** }} \\
\underline{0.135}\end{array}$ & $\begin{array}{l}0.492^{* * *} \\
\underline{0.136} \\
\end{array}$ & $\begin{array}{l}0.307^{* * *} \\
\underline{0.115}\end{array}$ \\
\hline $\mathrm{Z}_{2}^{4}$ & $\beta_{\mathrm{Z} 2}$ & & $\begin{array}{r}-0.111 \\
0.111\end{array}$ & \\
\hline $\mathrm{Z}_{3}$ & $\beta_{\mathrm{Z} 3}$ & & $\begin{array}{r}-0.133 \\
0.093 \\
\end{array}$ & \\
\hline Constant & $\delta_{0}$ & & & $\begin{array}{l}-0.435 \\
0.522 \\
\end{array}$ \\
\hline $\mathrm{T}$ & $\delta_{\mathrm{T}}$ & & & $\begin{array}{l}0.650^{* *} \\
0.367\end{array}$ \\
\hline $\mathrm{T}^{*} \mathrm{~T}$ & $\delta_{\mathrm{TT}}$ & & & $\begin{array}{l}-0.120 \text { ** } \\
\underline{0.060}\end{array}$ \\
\hline \multirow{4}{*}{\multicolumn{2}{|c|}{$\begin{array}{l}\text { Function Coefficient } \\
\text { Log Likelihood Function } \\
\sigma^{2}\end{array}$}} & 1.116 & 1.107 & 1.137 \\
\hline & & -17.026 & -15.821 & -19.270 \\
\hline & & $1.078^{*}$ & 0.895 & $0.256^{* * *}$ \\
\hline & & $\underline{0.596}$ & $\underline{0.571}$ & $\underline{0.062}$ \\
\hline \multicolumn{2}{|l|}{$\gamma$} & $0.964^{* * *}$ & $0.956^{* * *}$ & $0.999^{* * *}$ \\
\hline \multirow{2}{*}{\multicolumn{2}{|c|}{$\eta$}} & $\frac{0.023}{-0.305^{* * *}}$ & ${\frac{0.033}{-0.282^{* *}}}$ & $\underline{0.0001}$ \\
\hline & & 0.103 & 0.116 & \\
\hline
\end{tabular}

$1 * 10 \%$ level of significance, $* * 5 \%$ level of significance, $* * * 1 \%$ level of significance. ${ }^{2}$ Standard errors in italics.

${ }^{3}$ The dummy $\mathrm{DT}_{1}, 1996 / 97$, is excluded. ${ }^{4}$ The agro-climatic zone dummy $Z_{1}$ is excluded.
The partial output elasticities, given by the parameter estimates $\beta_{C}, \beta_{F}$ and $\beta_{L}$, allow the estimation of the function coefficient (table 3 ). The function coefficient parameter, a measure of returns to size (RTS), ranges from 1.107 for Model 2 to 1.137 for Model 3. This result reveals the presence of increasing returns to size, and suggests that the dairy farmers in the sample are operating at a suboptimal size, a finding that is consistent with the fact that all units in the sample are relatively small (table 2).

Table 4 presents results associated with various tests designed to evaluate the general specification of the models and the alternative formulation concerning the inefficiency component. The first test focuses on the statistical significance of the $\gamma$ parameter $\left(H_{0}: \gamma=0\right)$, which compares the stochastic frontier model versus the average production function. The closer $\gamma$ is to 1 , the more significant the presence of technical inefficiency is (Battese and Coelli 1992, Coelli 1996, and Coelli et al 1998). Hence, a value of 1.000 for $\gamma$ reveals that $100 \%$ of the variation in observed output from the frontier is due to inefficiency. The $\gamma$ parameters shown in table 3 range from 0.956 for Model 2 to 0.999 for Model 3 and the statistical test indicates that this parameter is significantly different from zero for the three models. Hence, the three $\gamma$ parameters reveal that most of the variation in observed output from the frontier is due to inefficiency.

The second step is to test the null hypothesis that the one-sided distribution is half-normal $\left(\mathrm{H}_{0}: \mu=0\right)$ and this hypothesis is accepted for all three models. This result indicates that the half-normal distribution is more compatible than the truncated-normal for the data under analysis. This result is consistent with several studies including Battese and Coelli (1992), Kumbhakar and Heshmati (1995), Ahmad and Bravo-Ureta (1996), Rezitis et al (2002), and Cullinae and Song (2003), among others.

Table 4. Statistical comparison between the three models. Comparación estadística entre los tres modelos.

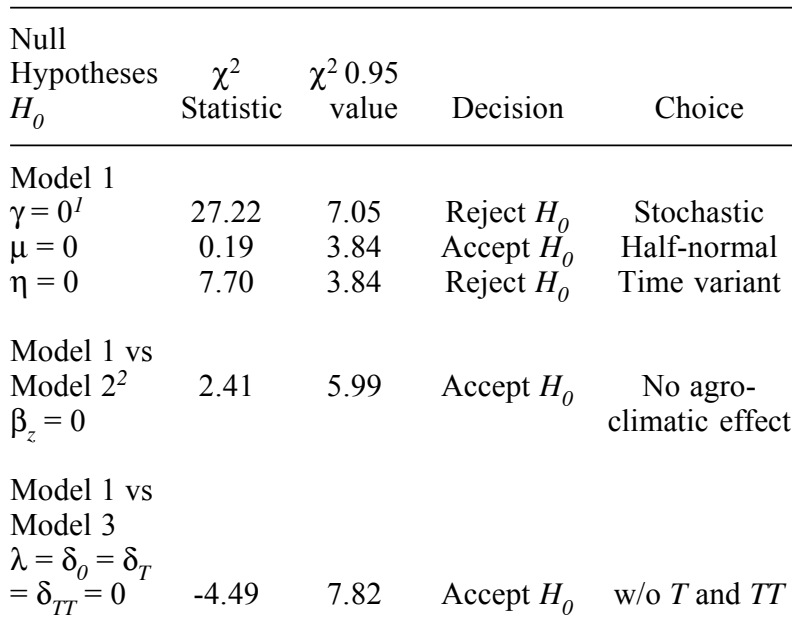

1 This statistic has a mixed $\mathrm{c}^{2}$ distribution.

2 Read as Restricted model versus Unrestricted model. 
The third step is to test the null hypothesis that technical efficiency is time invariant $\left(H_{0}: \eta=0\right)$, which is relevant only for Model 1 . This hypothesis is rejected at the $5 \%$ level of significance, which means that the technical efficiency is time variant. Moreover, $\eta$ has a negative value, suggesting that technical efficiency has decreased over time, a result that is similar to the one reported recently by Rivas (2003) for a sample Vermont dairy farms. This finding is not expected considering that the primary goal of the FMC is to enhance productivity.

Table 4 also shows the test of the significance of the agro-climatic effects. This test is performed by comparing Model 1 (Restricted model) and Model 2 (Unrestricted model). The results of a likelihood ratio test indicate that the agro-climatic effect is not significant at the $10 \%$ level; therefore, this effect does not improve the econometric estimates and Model 1 dominates Model 2. This result is in contrast with the findings of Demir and Mahmud (2002) who report a significant agro-climatic effect in their study of farm efficiency in Turkey.

Now, Model 1 (Restricted model with no explanatory variables in the inefficiency term) is tested against Model 3 (Unrestricted model with two explanatory variables, $T$ and $T T$, in the inefficiency term) where the latter corresponds to a Battese and Coelli (1995) specification. The results of a likelihood ratio test (table 4) indicate that Model 3 is not significant at the $10 \%$ level; therefore, Model 1 again is the dominant specification compared to Model 3.

In sum, of the three alternatives evaluated, the dominant specification is Model 1, which includes no agroclimatic zone effect and has no variables in the inefficiency component of the model.

Table 5, depicts technical efficiencies over time for each MCC for Model 1 as well as annual averages for all three models. These data show a large variation in efficiencies across farms, particularly at the end of the sample period. A decreasing level of technical efficiency over time is evident in the Paillaco, Ustaritz and La Misión MCCs. By contrast, the Pichirropulli and Pumol MCCs exhibit increasing technical efficiency from the first to the last year. The Santa Rosa MCC has a more erratic pattern which is likely due to the fact that the data for this MCC is extremely unbalanced (table 1), Pucara has a fairly constant technical efficiency value over time, and finally Reumén has data in only one year and thus no tendency can be observed.

The overall average annual estimated technical efficiency between 1996/97 and 2001/02 ranges from 69\% to $77 \%$ (table 5). All studies previously listed that use a stochastic frontier model have average technical efficiencies close to the results of this paper (e.g., Ahmad and Bravo-Ureta (1995) 77\%, Ahmad and Bravo-Ureta (1996) $86 \%$, Bailey et al (1989) 78\%, Battese and Coelli (1988) 70\%, Cuesta (2000) 78\%, Heshmati and Kumbhakar (1994) 81\%, Kumbhakar and Hjalmarsson (1993) 86\%,
Table 5. Technical efficiency measures for Model 1 (by period and $\mathrm{MCC}^{1}$ ). do y $\mathrm{CAL}^{2}$ ).

Medidas de eficiencia técnica para el Modelo 1 (por perío-

\begin{tabular}{lccccc}
\hline Period & 1996-97 & 1998-99 & 1999-00 & 2000-01 & 2001-02 \\
\hline Model 1 & & & & & \\
MCC & & & & & \\
Paillaco & & 0.75 & & & 0.59 \\
Reumén & & 0.74 & & & 0.67 \\
Pucara & & 0.69 & & & 0.66 \\
Ustaritz & & 0.74 & & & \\
La Misión & 0.76 & 0.71 & 0.59 & 0.42 & \\
Pichirropulli & 0.82 & 0.75 & 0.91 & 0.89 & 0.86 \\
Pumol & 0.70 & 0.67 & 0.66 & 0.66 & 0.76 \\
Santa Rosa & 0.79 & 0.72 & 0.93 & 0.78 & 0.73 \\
\hline Average & 0.77 & 0.72 & 0.71 & 0.69 & 0.72 \\
\hline
\end{tabular}

${ }^{1}$ Milk Collection Center.

${ }^{2}$ Centro de Acopio Lechero.

Kumbhakar and Heshmati (1995) 83\%, and Reinhard et al (1999) 89\%). Average technical efficiency across MCCs ranges from a high value for the Pichirropulli MCC (91\% in 1999/00) and the Santa Rosa MCC (93\% in 1999/00), and a minimum value in the 2000/01 for Pumol (42\%).

The effect of time $(D T s)$ on output is significant for all periods $\left(\beta_{D T 2}, \beta_{D T 3}, \beta_{D T 4}\right.$ and $\left.\beta_{D T 5}\right)$ with a year-to-year rate of technological change of 7.91\% (1998/99 over 1996/ 97), $13.48 \%$ (1999/00 over 1998/99), 24.45\% (2000/01 over $1999 / 00)$ and $-2.06 \%$ (2001/02 over $2000 / 01)$. The simple average annual rate of technological change over the $1996 / 2002$ period is $8.62 \%$. Ideally, one would have rates of technological change for non-FMC members in order to have a benchmark for comparison. However, no such data are available. Moreover, productivity studies for Chilean agriculture in general are very limited. Nevertheless, the estimated $8.62 \%$ rate of technological change is higher than the average annual total factor productivity (TFP) growth of $2.72 \%$ reported by Olavarría et al (2004) for the Chilean crop sector between 1961 and 1996. It is important to point out, however, that the TFP measure is a total productivity measure (i.e., includes both technological change and technical efficiency). Dairy studies using a decomposition methodology similar to the one used here report average annual rates of technological change equal to $-0.82 \%$ (Kumbhakar and Heshmati, 1995), 1.01\% (Ahmad and Bravo-Ureta, 1995), 3.4\% (Cuesta, 2000 ) and $1.10 \%$ (Rivas, 2003).

CONCLUDING REMARKS. This paper uses a stochastic production frontier model to measure technical efficiency and technological change for a sample of small dairy farms in Southern of Chile. The data is a highly unbalanced panel including 48 farmers from 1996/97 to 2001/02. In the preferred model, the inefficiency term has a half-normal dis- 
tribution, there is no agro-climatic effect, there is no improvement when the inefficiency term is explained by time and time square, the presence of technical inefficiency is highly significant and technical efficiency is time variant. Average technical efficiency ranges from 77\% (1996/97) to $69 \%(2000 / 01)$. Technological change is significant and increases at an average annual rate of $8.6 \%$ for the period $(1996 / 02)$. On average, small dairy farmers in Southern Chile (Paillaco) are operating at a sub optimal size given that the computed returns to size parameter is around 1.12.

In general, the results of this study indicate that there is substantial scope for improving technical efficiency in small dairy farms in the Paillaco area of Southern Chile. In addition, given that there is a wide variation in the level of technical efficiency across individual farms, the potential for increasing farm output, competitiveness and profitability through the efficient use of existing inputs varies greatly across units. Unfortunately, the available data does not make it possible to examine the determinants of efficiency in order to formulate recommendations on this regard.

An important limitation of this study is that the lack of data for farmers that are not participating in an FMC does not make it possible to identify the differential impact of this program on productivity. It could well be the case that non-members have higher inefficiency and lower technological progress that what has been measured in this study for the sample of members. If this were the case, then the implication would be that the FMCs are indeed accomplishing their mission and that what might be required is a longer period of time as an FMC member before farmers can adopt and become familiar with the practices being promoted and thus get closer to the frontier. This is an important question to address given the amount of resources that the Chilean government is allocating to promote FMCs. Therefore, the government should provide mechanisms that can be used to collect and analyze the data that are required to make a comparative analysis between FMC members and non-members.

Medidas de eficiencia técnica para pequeños productores de leche del Sur de Chile: Un análisis con fronteras estocásticas y datos de panel desbalanceado

\section{RESUMEN}

Este trabajo emplea fronteras de producción estocásticas para medir la efíciencia técnica y el cambio tecnológico en una muestra de predios de pequeños productores lecheros del Sur de Chile. Los datos constituyen un panel altamente desbalanceado e incluyen 48 predios con un total de 92 observaciones para los ejercicios 1996/97 a 2001/02. Todos los agricultores de la muestra son miembros del Centro de Gestión de Paillaco (CEGE-Paillaco). En el modelo seleccionado, el término de inefíciencia tiene una distribución seminormal, no hay efecto agroclimático y la presencia de ineficiencia técnica es altamente significativa y variable en el tiempo. El promedio de la eficiencia técnica fluctúa desde $77 \%$
(1996/97) a 69\% (2000/01). El cambio tecnológico es significativo y aumenta a una tasa anual promedio de $8,6 \%$ para el período en estudio (1996/02). En promedio, los predios de la muestra de Paillaco están operando a un tamaño subóptimo, ya que el parámetro para el retorno a escala es 1,12 .

\section{ACKNOWLEDGMENTS}

The authors are thankful to the staff from the Paillaco FMC and to the staff and farmers of the MCCs for providing the data used in this study. In addition, the authors gratefully acknowledge the comments made by participants to the VIII European Workshop on Efficiency and Productivity in Oviedo, Spain, and by anonymous reviewers on earlier drafts of the paper.

\section{REFERENCES}

Ahmad, M. 1994. An Econometric Analysis of Output Growth Using Panel Data: The Case of Vermont Dairy Farms. Ph. D. Dissertation, Agricultural and Resource Economics Department, University of Connecticut.

Ahmad M, B E Bravo-Ureta. 1995. An Econometric Decomposition of Dairy Output Growth. Am J Agr Econ 77: 914-921

Ahmad M, B E Bravo-Ureta. 1996. Technical Efficiency Measures for Dairy Farms Using Panel Data: A Comparison of Alternative Model Specifications. J Prod Anal 7: 399415.

Alvarez A, E Gonzales. 1999. Using Cross-section Data to Adjust Technical Efficiency Indexes Estimated with Panel Data. Am J Agr Eco 81: 894.

Anrique R. 1999. Caracterización del Chile Lechero. Competitividad de la Producción Lechera Nacional. Chapter I. pp. 1-33. Universidad Austral de Chile. Agricultural Science Department. Valdivia, Chile.

Bailey D, B Biswas, S C Kumbhakar, K Schulthies. 1989. An Analysis of Technical, Allocative, and Scale Inefficiency: The Case of Ecuadorian Dairy Farms. West J Agr Econ 14: 30-37.

Battese G E, S S Broca. 1997. Functional Forms of Stochastic Frontier Production Functions and Models for Technical Inefficiency Effects: A Comparative Study for Wheat Farmers in Pakistan. J Prod Anal 8: 395-414.

Battese G E, T J Coelli. 1988. Prediction of Firm-Level Technical Efficiencies with a Generalized Frontier Production Function and Panel Data. J Econometrics 38: 387-389.

Battese G E, T J Coelli. 1992. Frontier Production Functions, Technical Efficiency and Panel Data: With Application to Paddy Farmers in India. J Prod Anal 3: 153-69.

Battese G E, T J Coelli. 1995. A Model for Technical Inefficiency Effects in a Stochastic Frontier Production Function for Panel Data. Empirical Econ 20: 325-332.

Battese G E, G S Corra. 1977. Estimation of a Production Frontier Model: With Application to the Pastoral Zone of Eastern Australia. Aust J Agr Econ 3: 169-179.

Coelli T J. 1996. A Guide to FRONTIER Version 4.1: A Computer Program for Stochastic Frontier Production and Cost Function Estimation. CEPA Working Paper 96/7, Department of Econometrics, University of New England, Armidale NSW Australia. 
Coelli T J, D S Rao, G E Battese. 1998. An Introduction to Efficiency and Productivity Analysis. Boston: Kluwer Academic Publishers.

Cuesta R. 2000. A Production Model with Firm-specific Temporal Variation Technical Inefficiency: with Application to Spanish Dairy Farms. J Prod Anal 13: 139-158.

Cullinae K, D Song. 2003. A Stochastic Frontier Model of the Productive Efficiency of Korean Container Terminals. Appl Econ 35: 251

Demir N, S F Mahmud. 2002. Agro-Climatic Conditions and Regional Technical Inefficiencies in Agriculture. Can J Agr Econ 50: 269-280.

Guichapani A. 2004. Evaluación del Comportamiento de la Producción de Leche de los Centros de Acopio adscritos al CEGE Paillaco. B.S. Thesis, School of Agrarian Sciences, University Austral de Chile.

Heshmati A, S C Kumbhakar. 1994. Farm Heterogeneity and Technical Efficiency: Some Results from Swedish Dairy Farm. J Prod Anal 5: 45-61.

Instituto Interamericano de Cooperación para la Agricultura, IICA. 2002. Formación del Agricultor Profesional. IICA Agency of Cooperation in Chile. Santiago, Chile.

Jondrow J, C A K Lovell, I S Materov, P Schmidt. 1982. On the Estimation of Technical Inefficiency in the Stochastic Frontier Production Function Model. J Econ 19: 233-238.

Kumbhakar S C, A Heshmati. 1995. Efficiency Measurement in Swedish Dairy Farms: An Application of Rotating Panel Data, 1976-88. Am J Agr Econ 77: 660-674.

Kumbhakar S C, L Hjalmarsson. 1993. Technical Efficiency and Technical Progress in Swedish Dairy Farms. The
Measurement of Productive Efficiency Techniques and Applications. H.O. Fried, C.A.K. Lovell and P. Schmidt (eds). Oxford University Press, New York, 257-270.

Kumbhakar S C, S Ghosh, J T Mcguckin. 1991. A Generalized Production Frontier Approach for Estimating Determinants of Inefficiency in U.S. Dairy Farms. J Bus Econ Stat 9: 279-286

Olavarría J, B E Bravo-Ureta, H Cocchi. 2005. Productividad Total de los Factores en la Agricultura Chilena: 1961-1996. Econ Agr Rec Nat: Forthcoming.

Reifschneider D, R Stevenson. 1991. Systematic Departures from the Frontier: A Framework for the Analysis of Firm Inefficiency. Int Econ Rev 32: 715-723.

Reinhard S, C A K Lovell, G Thijssen. 1999. Econometric Estimation of Technical and Environmental Efficiency: an Application to Dutch Dairy Farms. Am J Agr Econ, 81: 44.

Rezitis A N, K Tsiboukas, S Tsoukalas. 2002. Measuring Technical Efficiency in the Greek Agricultural Sector. Appl Econ 11: 1345.

Sandoval C, J I Gómez. 1999. Los centros de gestión empresarial en Chile. Agricultural Development Institute (INDAP), Chilean Ministry of Agriculture. Santiago, Chile.

Rivas T E. 2003. Dairy Farm Efficiency and the Analysis of Milk Production Growth: Evidence from Vermont. Ph. $D$. Dissertation, Agricultural and Resource Economics Department, University of Connecticut.

Vargas, G. 2000. Economía y gestión de la producción lechera. Agro-industrial Department, Fundación Chile. Santiago, Chile. 